Manuscript of paper published in Accident and Analysis and Prevention, Volume 41 (2009), 48-56

\title{
INTERACTIONS BETWEEN RAIL AND ROAD SAFETY IN GREAT BRITAIN
}

\author{
Andrew W Evans \\ Department of Civil and Environmental Engineering \\ Imperial College London \\ London SW7 2AZ, UK \\ a.evans@imperial.ac.uk \\ Tel: +44 2075946043 \\ Fax: 442075946102 \\ and \\ John D Addison \\ Department of Civil and Environmental Engineering \\ University College London \\ London WC1E 6BT, UK \\ puff@transport.ucl.ac.uk \\ Tel: +44207679 1572
}

Revised: June 2008

\begin{abstract}
This paper discusses the results of an investigation into ways in which the safety risks of travel on road and rail interact with each other in Great Britain, other than through physical contact such as at level crossings. The two main foci of the paper are: (1) an analysis of the 'whole journey' risks of journeys for which the national rail system is the main mode, but which also include stages by other transport modes to provide access to the railway system; and (2) an analysis of the effect on safety risk of intermodal transfers between rail and road. On (1), walking to and from stations was estimated to account on average for $65 \%$ of the overall door-to-door risk of being killed on rail journeys; the rail system itself accounts for $21 \%$ of the risk, and other access modes account for the remaining $14 \%$. The average distance walked to and from stations is $0.9 \mathrm{~km}$ per rail journey, and this walking accounts for $5 \%$ of all walking nationally. On (2), it was found that increasing rail fares to fund railway safety measures may lead passengers to switch from rail to car, but for most sensible rail safety measures, the additional risks from such diversions are small compared with the intended rail safety benefits. However, for high-cost rail safety measures funded by passengers, the additional risks from diversions may be of the same order as the intended safety benefits. The last section of the paper explores the effects of variations in the casualty rates of rail users as pedestrians and car users, because their road risks may be different from those of all road users. Such variations could alter the detailed conclusions of the paper, but the scale of such effects appears to be modest.
\end{abstract}

\section{KEYWORDS}

Railways; roads; safety; accidents; risk; modal shift 


\section{INTRODUCTION}

Safety is one of the five primary objectives of integrated transport policy in Britain ${ }^{1}$, but safety policies themselves are generally developed separately for each mode. In practice both achieved levels of safety and safety expenditure relative to risks are higher for the public transport modes than they are for the roads. This leads to questions about whether safety resources are used to best effect.

Although they are separately managed, there are some strong interactions between rail and road safety. The most obvious of these interactions are at the physical interfaces between the rail and road systems: these include collisions at level crossings and bridges. Level crossings now contribute the greatest potential for catastrophic risk on the railway and they accounted for $36 \%$ of all railway fatalities in the four years to 2003/04. However, this paper focuses on interactions other than the physical interfaces, though the physical interfaces are implicitly included in the risk estimates presented. The two foci of the present paper are

(1) an analysis of the 'whole journey' risks of journeys for which the national rail system is the main mode, but which also include stages by other transport modes to provide access to the railway system; and

(2) an analysis of the effect on safety risk of inter-modal transfers between rail and road.

The reason for concentrating on these is that they are important but less investigated than the physical interfaces, which are the subject of other research projects. The previous literature on the interaction between road and rail risks as discussed in this paper is limited. Jorgensen (1993) is an interesting paper with similarities to the present one that considers risks on commuting journeys in Copenhagen when undertaken by different modes. L Evans et al (1990) compared the safety of driving and flying in the Unites States: we refer to their paper below.

The principal results presented here are for Great Britain as a whole, though some results on rail travel patterns are separately presented for journeys wholly in London, journeys with one end in London, and journeys with neither end in London. The primary data sources are:

(1) the British National Travel Survey (NTS) for 1999-2001 for data on the patterns of national rail use, on modes by which national rail travellers reach railway stations, and for the development of a rail/car modal shift model; and

(2) data on the risks of death and injury per passenger-km for national rail travel, for car travel, and for all access modes. These data cover casualties both to the travellers themselves and to others affected, such as pedestrians in the case of motorised road travel, and level crossing users in the case of rail travel. These data are based on various periods of up to five years ending in 2003.

Figure 1 shows the structure of the paper following this introduction. Section 2 presents data analysed from the NTS on the access stages of journeys for which main-line rail (labelled 'surface rail' in the NTS) is the main mode. Section 3 presents estimates of casualty risks by mode, both for travellers themselves and for other people affected. Section 4 combines the results of sections 2 and 3 to give 'whole journey' risks for journeys with rail as main mode. Section 5 estimates the effects on casualties of the switching of journeys between rail and car, using the modal risks from section 3 and the 'whole journey' risks of rail journeys from section 4. Section 6 presents a modal split model estimating in particular the response of travellers to increases in rail fares. Section 7 combines this model with the results of section 5 to estimate the net effects on safety of two representative rail safety measures funded by passenger fare increases, taking account of the effect of such increases in inducing diversions from rail to car. Finally, it is possible that the risks for the rail using population when

\footnotetext{
${ }^{1}$ The other four primary objectives are environment, economy, accessibility and integration.
} 
walking or driving differ from those of the population as a whole. Section 8 considers reasons for this, and explores the effect of different risks on the results.

Figure 1: Structure of paper

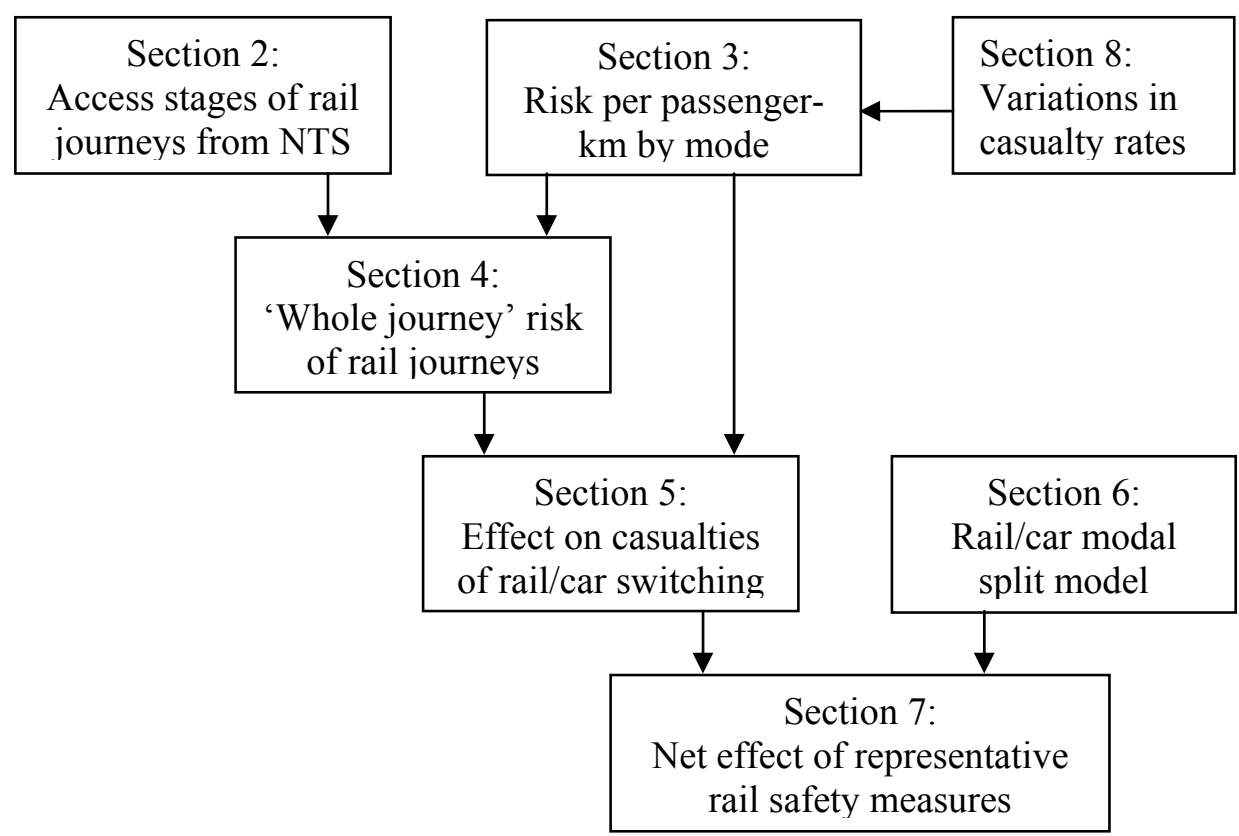

\section{JOURNEYS FOR WHICH SURFACE RAIL IS THE MAIN MODE}

The National Travel Survey (NTS) collects information about all journeys made by respondents in a period of seven consecutive days beginning on a random day of the week. The NTS defines a (oneway) journey as set of 1 or more stages by different modes, illustrated by the 4-stage journey to work in Figure 2 that includes one stage each by car, rail, bus and walking. The NTS defines the 'main mode' of a journey as the mode with the longest stage. The NTS defines 'surface rail' as the main line or 'national' or ex-British Rail network, and these terms are used interchangeably. Surface rail does not include the London Underground or other metros, which are treated as different modes.

Walk stages of more than 50 yards are included in the NTS, but, in order to reduce the burden on respondents, walk stages of less than 1 mile are recorded only on the seventh day. Therefore walk stages of less than 1 mile need separate analysis and multiplication by 7 before being recombined with the other data. There is some evidence that walk stages of 1 mile or more, which should be recorded in full on the first six days, are somewhat under-recorded, but in the present work no adjustments are made for that.

Figure 2: Illustration of stages in a journey

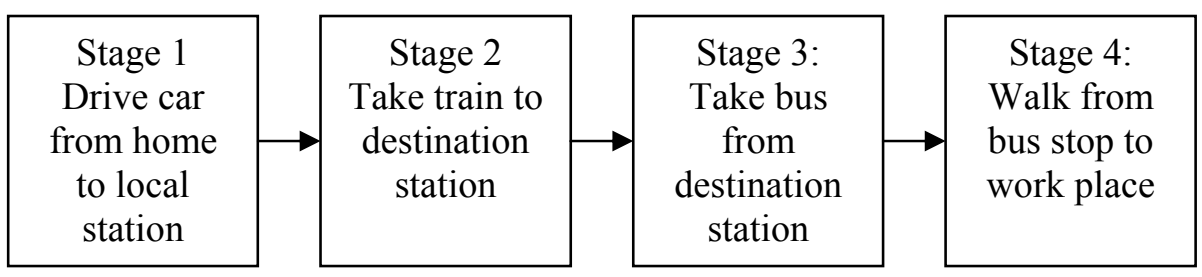


Table 1: Average number of stages per journey for journeys with different main modes

\begin{tabular}{|lr|}
\hline Main mode & $\begin{array}{r}\text { Average number of } \\
\text { stages per journey }\end{array}$ \\
\hline Walk & 1.0 \\
Car & 1.0 \\
Taxi & 1.0 \\
Other private & 1.1 \\
Local bus & 1.7 \\
London Underground & 2.6 \\
Surface rail & 2.9 \\
\hline Source: Department for & Transport $(2002)$, \\
Table 3.9 & \\
\hline
\end{tabular}

Table 2: Average number of stages per journey on journeys with surface rail as main mode

\begin{tabular}{|lrrrr|}
\hline Mode & $\begin{array}{r}\text { Within } \\
\text { London }\end{array}$ & $\begin{array}{r}\text { One end } \\
\text { London }\end{array}$ & $\begin{array}{r}\text { Not } \\
\text { London }\end{array}$ & Great Britain \\
\hline Main surface rail & 1.000 & 1.000 & 1.000 & 1.000 \\
Secondary surface rail & 0.002 & 0.017 & 0.018 & 0.013 \\
Air & 0.000 & 0.000 & 0.000 & 0.000 \\
London Underground, light rail & 0.279 & 0.424 & 0.021 & 0.218 \\
Car, taxi, other private & 0.130 & 0.495 & 0.319 & 0.311 \\
Bus or coach & 0.205 & 0.137 & 0.131 & 0.156 \\
Bicycle & 0.007 & 0.016 & 0.022 & 0.016 \\
Walk & 1.242 & 1.046 & 0.917 & 1.056 \\
\hline Total & 2.865 & 3.137 & 2.429 & 2.770 \\
\hline
\end{tabular}

Table 3: Average distance travelled per journey on journeys with surface rail as main mode including access (kilometres)

\begin{tabular}{|lrrrr|}
\hline Mode & $\begin{array}{r}\text { Within } \\
\text { London }\end{array}$ & $\begin{array}{r}\text { One end } \\
\text { London }\end{array}$ & $\begin{array}{r}\text { Not } \\
\text { London }\end{array}$ & Great Britain \\
\hline Main surface rail & 16.573 & 77.575 & 42.924 & 44.738 \\
Secondary surface rail & 0.009 & 0.240 & 0.715 & 0.358 \\
Air & 0.000 & 0.000 & 0.077 & 0.031 \\
London Underground, light rail & 1.273 & 3.038 & 0.160 & 1.339 \\
Car, taxi, other private & 0.432 & 3.690 & 2.561 & 2.225 \\
Bus or coach & 0.587 & 0.645 & 0.896 & 0.727 \\
Bicycle & 0.028 & 0.054 & 0.078 & 0.056 \\
Walk & 1.077 & 0.872 & 0.795 & 0.905 \\
\hline Total & 19.979 & 86.115 & 48.206 & 50.379 \\
\hline
\end{tabular}

There were 5,749 journeys in the NTS for 1999-2001 for which surface rail was the main mode. Most of these involved a single surface rail stage, but the journeys also included 74 second or third surface rail stages, which are described in the tables below as 'secondary rail'. In addition, there were 202 surface rail stages on journeys for which another mode was the main mode (such as rail stages to airports for domestic air journeys); these other journeys are disregarded in the analysis. Of the 5,749 journeys, 1,791 (31\%) were wholly within London, 1,663 (29\%) had one end in London, and 2,295 $(40 \%)$ had both ends outside London. Table 1 gives the average number of stages by each mode per journey for which surface rail was the main mode, and Table 2 gives the average distance travelled on these journeys by each mode, including the access modes. It will be seen from Table 2 that the average 
access distance travelled per rail journey for some modes - such as bicycle - is low. This is not because access journeys by bicycle are necessarily short, but because bicycles are used relatively infrequently in Britain to access railway stations.

The most notable feature of the results in Tables 1 and 2 is the importance of walking as an access mode on surface rail journeys. Table 1 shows that on average surface rail journeys included 1.77 stages in addition to the main rail stage itself. Of these access stages, 1.06 were walks, and 0.71 were by all other modes combined.

Table 2 shows that the average distance walked was $0.905 \mathrm{~km}$ per rail journey. Given that there were about 950 million surface rail journeys per year in 1999-2001 (Strategic Rail Authority 2005, Table 1.2a) this implies that about 860 million person-kilometres per year would have been walked in connection with surface rail journeys, or an average of $14.8 \mathrm{~km}$ per person in Great Britain. The average total distance walked for all purposes was 304 kilometres per person (Department for Transport (DfT) 2002, Table 3.1), so the proportion of all walking made in connection with surface rail journeys was just under 5\%. In passing, it may be noted that there is likely to be a similar amount of walking per journey on journeys made with the London Underground as main mode, of which there were also about 950 million per year in 1999-2001. If so, it would follow that about $10 \%$ of all walking nationally is in connection with rail journeys.

\section{RISK OF CASUALTIES PER PASSENGER-KILOMETRE}

Table 3 gives the adopted risks per passenger-kilometre travelled on the relevant modes, measured in various ways. The first column of data gives fatalities to travellers or passengers per billion travelled$\mathrm{km}$. The second column gives fatalities to other people per billion travelled-km; 'other people' consist of staff and members of the public including those at level crossings (but excluding trespassers) for the rail modes; pedestrians and drivers for buses; and pedestrians for the private road modes. The third column is the sum of the first two. The fourth to sixth columns give corresponding rates for the sum of fatalities and weighted serious injuries. The weight adopted for serious injuries relative to fatalities is $11.24 \%$. This is the DfT's valuation of a serious injury relative to a fatality in 2003 , which was $£ 147,460 / £ 1,312,260$ (Department for Transport 2004a). The discussion in this paper focuses on the results for fatalities, but the results for the sum of fatalities and weighted injuries are presented in the tables alongside those for fatalities. The qualitative results for the two risk measures are similar, but there are quantitative differences. The rates in Table 3 are for accidents involving vehicles. The authors have also briefly considered accidental fatalities to people on the highway or at railway stations not involving road or rail vehicles, such as from falls on the pavement or down stairs, but these are not reported here.

Table 4: Casualties involving vehicles per billion passenger-kilometres: Great Britain 2003

\begin{tabular}{|l|rrr|rrr|}
\hline & \multicolumn{3}{|c|}{ Fatalities only } & \multicolumn{3}{c|}{$\begin{array}{c}\text { Fatalities and weighted } \\
\text { serious injuries }\end{array}$} \\
\hline Transport \\
mode & $\begin{array}{l}\text { Trav- } \\
\text { ellers }\end{array}$ & Others & All & $\begin{array}{l}\text { Trav- } \\
\text { ellers }\end{array}$ & & Others \\
\hline Surface rail & 0.279 & 0.456 & 0.735 & 0.478 & 0.547 & 1.025 \\
Air & 0.00 & 0 & 0 & 0.0001 & 0 & 0.0001 \\
LUL, light rail & 0.379 & 0 & 0.379 & 0.651 & 0 & 0.651 \\
Car or taxi & 2.696 & 0.875 & 3.571 & 5.354 & 1.921 & 7.275 \\
Bus or coach & 0.272 & 1.437 & 1.709 & 1.497 & 2.476 & 3.973 \\
Bicycle & 25.3 & 0.594 & 25.894 & 82.497 & 1.882 & 84.379 \\
Walk & 41.7 & 0 & 41.7 & 89.233 & 0 & 89.233 \\
\hline
\end{tabular}


The sources of the accident rates in Table 3 are various: they include the Department of Transport's estimated modal fatality rates for travellers (DfT 2005), the Health and Safety Executive's (HSE) annual railway safety reports (HSE 2004 and predecessors), the Railway Group Annual Safety Performance Report (Rail Safety and Standards Board (RSSB) 2005a), and Road Casualties Great Britain (DfT 2004b and predecessors). The rates are generally based on observed fatalities and injuries, but the railway data were also checked for consistency with the RSSB's Safety Risk Model (RSSB 2005b).

The most important features of Table 3 are the relative fatality rates per traveller-kilometre for surface rail, car travel and walking. The traveller fatality rate for car travel is about 10 times greater than for rail travel, and that for walking is about 150 times greater than for rail travel. The corresponding ratios including fatalities to non-travellers are about 5 for car relative to surface rail and 60 for walking relative to surface rail.

\section{4. 'WHOLE JOURNEY’ RISKS FOR JOURNEYS WITH RAIL AS MAIN MODE}

Table 4 combines the average distances travelled on the different stages of journeys with surface rail as main mode in Great Britain in Table 2 with the casualty rates in Table 3 to give casualties per billion surface rail journeys, including access. The remarkable feature is the contribution walking makes to overall risks. This is because walking is an important mode of access and because it has relatively high casualty rates. Table 4 shows that, for travellers only, $21 \%$ of the 'whole journey' risk is on the railway system, $65 \%$ is in walking to and from stations, and the remaining $14 \%$ is on other access modes. When fatalities to non-travellers are added, the proportion attributed to walking declines because walking imposes no transport risk on others. In that case, the proportions are $40 \%$ on the rail system, $46 \%$ in walking and $14 \%$ on other modes. It may be noted that the $40 \%$ on the rail system includes the relatively large number of casualties to level crossing users, which are often related to misuse of the level crossing.

Table 5: Casualties per billion passenger-journeys with surface rail as main mode including access: Great Britain: 2003

\begin{tabular}{|l|rrr|rrr|}
\hline & \multicolumn{3}{|c|}{ Fatalities only } & \multicolumn{3}{c|}{ Fatalities and weighted } \\
serious injuries \\
\hline Transport mode & Traveller & Other & All & Traveller & Other & All \\
\hline Main surface rail & & & & & & \\
Secondary surface rail & 12.47 & 20.40 & 32.87 & 21.38 & 24.49 & 45.87 \\
Air & 0.10 & 0.16 & 0.26 & 0.17 & 0.20 & 0.37 \\
LUL, light rail & 0.00 & 0 & 0 & 0.00 & 0 & 0 \\
Car or taxi & 0.51 & 0 & 0.51 & 0.87 & 0 & 0.87 \\
Bus or coach & 6.00 & 1.95 & 7.94 & 11.91 & 4.27 & 16.18 \\
Bicycle & 0.20 & 1.05 & 1.24 & 1.09 & 1.80 & 2.89 \\
Walk & 1.41 & 0.03 & 1.44 & 4.60 & 0.10 & 4.71 \\
\hline All surface rail stages & 37.74 & 0 & 37.74 & 80.76 & 0 & 80.76 \\
Non-surface rail stages & 12.57 & 20.56 & 33.13 & 21.56 & 24.68 & 46.24 \\
\hline All journey stages & 45.85 & 3.02 & 48.87 & 99.23 & 6.18 & 105.41 \\
\hline
\end{tabular}

\section{EFFECT ON RISK OF DIVERTING JOURNEYS FROM RAIL TO CAR}

Table 5 uses the average distances in Table 2 and the casualty rates in Table 3 to estimate the effects on casualties of diverting journeys from rail to car. The table assumes that the average rail journey and its access stages are replaced by a single-stage journey made by car, with no access stages. The car 
distance is assumed to be equal to the total distance of the original journey, including the access stages.

Table 6: Effect on casualties per journey of switching journeys between surface rail and car as main mode: Great Britain: 2003

\begin{tabular}{|c|c|c|c|c|c|c|}
\hline & \multicolumn{3}{|c|}{$\begin{array}{l}\text { Fatalities per billion } \\
\text { traveller-journeys }\end{array}$} & \multicolumn{3}{|c|}{$\begin{array}{c}\text { Fatalities and weighted } \\
\text { serious injuries per billion } \\
\text { traveller-journeys }\end{array}$} \\
\hline & $\begin{array}{l}\text { Trav- } \\
\text { ellers }\end{array}$ & Others & All & $\begin{array}{l}\text { Trav- } \\
\text { ellers }\end{array}$ & Others & All \\
\hline \multicolumn{7}{|l|}{ Rail } \\
\hline Main rail stage & 12.47 & 20.40 & 32.87 & 21.38 & 24.48 & 45.87 \\
\hline Access stages & 45.95 & 3.19 & 49.14 & 99.40 & 6.38 & 105.78 \\
\hline All journey stages & 58.42 & 23.59 & 82.01 & 120.79 & 30.86 & 151.65 \\
\hline \multicolumn{7}{|l|}{ Car } \\
\hline Single stage & 135.82 & 44.07 & 179.89 & 269.73 & 96.79 & 366.52 \\
\hline Change in casualties & +77.40 & +20.48 & +97.88 & +148.94 & +67.70 & +216.64 \\
\hline Ratio: Car/rail & 2.32 & 1.87 & 2.19 & 2.23 & 3.14 & 2.42 \\
\hline
\end{tabular}

The justification for disregarding any access stages for car journeys is the finding from NTS data that journeys by car as main mode have generally very few access stages: the average number of additional stages for car drivers and passengers per main-mode car journey was only 0.03 in 1999-2001 (DfT 2002, Table 3.9), compared with 1.77 additional stages for surface rail travellers in Table 1 above. The figure of 0.03 is even lower at 0.02 in the more recent report on the 2002-2003 NTS (DfT, 2005b, Table 2.3).

It is possible that rail-replacement car journeys would travel a greater proportion of their distance on motorways than the overall national proportion of $18 \%$ (DfT 2004c, Table 7.4), and therefore be rather safer. On the other hand, the average distance of rail journeys in Table 2 is only about $50 \mathrm{~km}$, including access, so any such effect is likely to be small.

The main conclusion from Table 5 is that the diversion of journeys from rail to car increases fatalities both to travellers and to others as would be expected, but only by factors of just over 2 rather than by higher factors that would be expected from a simple comparison of the main-mode casualty rates in Table 3. This is mainly because travel by car avoids the relatively high-risk walk stages of rail journeys.

\section{RAIL/CAR MODAL SPLIT MODEL}

Rail safety measures, such as advanced train control systems, can sometimes be expensive but they may save few casualties, because rail systems are already relatively safe. Furthermore, the majority of rail passenger fatalities do not occur in the high-profile train collisions and derailments, but in personal accidents such as passengers falling in front of trains, and these are not reduced by measures such as advanced train control systems. If high-cost rail safety measures are funded by passengers through higher fares, it is possible in principle for some passengers to be diverted from rail to car, and for the additional casualties caused by the car travel to outweigh the casualty savings on the rail system itself. In that case, the net effect of the safety measure would be to increase casualties, not reduce them. This possibility is investigated in this and the following section. 
The first step in the investigation is the development of a modal split model for the choice between rail and car. Binomial Logit models were used, in which the probability of choosing rail was the dependent variable, and rail fare was one of the independent variables. This model was based on the NTS data. Separate models were developed for the three regional groupings of journeys within London, journeys with one end in London, and journeys with neither end in London, and for Great Britain as a whole. The sum of the three regions gives results similar to those for Great Britain as a whole, so to estimate the national effects of safety measures the model for Great Britain is used. Table 6 shows the explanatory variables in the final models with their standard errors. All the coefficients in the final models are statistically significantly different from zero, and all have the expected signs. In particular, increasing the rail fare reduces the probability of choosing rail.

The modal split model was estimated for and applied to only travellers who are presumed to have a choice between rail and car. Rail users who do not hold a driving licence and/or who are from non-car owning households are presumed to be 'captive' to rail, and not have a choice. Car users from NTS 'Primary Sampling Units' (i.e. local areas) from which no rail journey was made by anyone to any destination are presumed to have no viable rail service, and thus be captive to car. Table 7 shows the proportions of captive and non-captive rail users on this definition. The fitting of the model was based on eligible journeys for which a cost or fare for the not-used mode (car for rail journeys and rail for car journeys) could be imputed from similar journeys in the NTS dataset.

Table 7 shows the estimated elasticity of the non-captive rail journeys with respect to fares from the modal split models, and thence the rate at which rail users would transfer to car as a result of fare rises. The national number of rail journeys is currently about 1 billion per year. (According to the SRA 2005, there were 976 million passenger-journeys in 2002-03 and 1,014 in 2003-04.) The illustrative results in the bottom right of Table 7 therefore indicate that about 1.5 million would transfer to car given a $0.5 \%$ rise in fares, and 15 million given a $5 \%$ rise in fares.

Table 7: Coefficients (with standard errors in brackets) in logit models for probability of non-captive users choosing rail

\begin{tabular}{|lrrrr|}
\hline Mode & $\begin{array}{r}\text { Within } \\
\text { London }\end{array}$ & $\begin{array}{r}\text { One end } \\
\text { London }\end{array}$ & Not London & Great Britain \\
\hline Intercept & -2.262 & -1.716 & -5.207 & -4.506 \\
& $(0.3672)$ & $(0.2323)$ & $(0.5582)$ & $(0.3182)$ \\
\hline Journey length $(\mathrm{km})$ & $\begin{array}{r}8.987 * 10^{-2} \\
\left(0.9507 * 10^{-2}\right)\end{array}$ & $\begin{array}{r}1.358^{*} 10^{-2} \\
\left(0.1845^{*} 10^{-2}\right)\end{array}$ & $\begin{array}{r}1.656^{*} 10^{-2} \\
\left(0.2410^{*} 10^{-2}\right)\end{array}$ & $\begin{array}{r}1.739^{*} 10^{-2} \\
\left(0.1444^{*} 10^{-2}\right)\end{array}$ \\
\hline Car cost (pence/km) & & & $2.447^{*} 10^{-1}$ & $1.748^{*} 10^{-1}$ \\
& & & $\left(0.6668^{*} 10^{-1}\right)$ & $\left(0.3381^{*} 10^{-1}\right)$ \\
\hline Rail fare (pence/km) & $-1.068^{*} 10^{-1}$ & $-4.078^{*} 10^{-2}$ & $-6.166^{*} 10^{-2}$ & $-5.204^{*} 10^{-2}$ \\
& $\left(0.1762 * 10^{-1}\right)$ & $\left(1.075^{*} 10^{-2}\right)$ & $\left(1.995^{*} 10^{-2}\right)$ & $\left(0.9157^{-2} 10^{-2}\right)$ \\
\hline $\begin{array}{l}\text { Walk time to station } \\
\text { (minutes) }\end{array}$ & $-6.274^{*} 10^{-2}$ & & $-2.622^{*} 10^{-2}$ & $-3.334^{*} 10^{-2}$ \\
\hline $\begin{array}{l}\text { Household income } \\
\text { (£/year) }\end{array}$ & $\left(1.162^{*} 10^{-2}\right)$ & & $\left(0.6909 * 10^{-2}\right)$ & $\left(0.4126^{*} 10^{-2}\right)$ \\
\hline
\end{tabular}


Table 8: Journeys with surface rail as main mode

\begin{tabular}{|lrrrrr|}
\hline Mode & $\begin{array}{r}\text { Within } \\
\text { London }\end{array}$ & $\begin{array}{r}\text { One end } \\
\text { London }\end{array}$ & $\begin{array}{r}\text { Not } \\
\text { London }\end{array}$ & $\begin{array}{r}\text { Sum of 3 } \\
\text { regions }\end{array}$ & $\begin{array}{r}\text { Great } \\
\text { Britain }\end{array}$ \\
\hline $\begin{array}{l}\text { Distribution of rail journeys in 1999- } \\
\text { 2001 NTS (100\% = 5,749) }\end{array}$ & & & & \\
'Captive' to rail & $12.30 \%$ & $6.47 \%$ & $20.42 \%$ & \\
Not 'captive' to rail & $18.86 \%$ & $22.46 \%$ & $19.50 \%$ & & \\
All & $31.15 \%$ & $28.93 \%$ & $39.92 \%$ & & $100.81 \%$ \\
\hline $\begin{array}{l}\text { Modelled elasticity of 'non-captive' } \\
\text { rail journeys with respect to fare }\end{array}$ & -0.860 & -0.279 & -0.543 & & -0.489 \\
\hline Rail journeys transferring to car per & & & & & \\
unit of national total for & & & & & \\
$\quad \begin{array}{l}\text { 0.5\% rise in rail fares } \\
\text { 5\% rise in rail fares }\end{array}$ & 0.000809 & 0.000313 & 0.000528 & 0.001649 & 0.001484 \\
& 0.007893 & 0.003104 & 0.005193 & 0.016190 & 0.014623 \\
\hline
\end{tabular}

\section{IMPLICATIONS FOR SAFETY MEASURES}

The next step in investigating the effect of rail safety measures funded by fares is to combine the results of modal split model in section 6 with the casualty rates in section 5. It is possible to use these results to consider any combination of safety reductions and fare rises. For the purposes of illustration, Table 8 presents results for two representative combinations:

(1) a safety measure, or set of safety measures, reducing all surface railway risk, including risk to non-passengers, by $10 \%$, funded by a $0.5 \%$ rise in fares; and

(2) a safety measure reducing risk only to rail passengers by $10 \%$, funded by a $5 \%$ increase in fares.

The results in Table 8 are expressed in changes in casualties per billion (initial) passenger journeys. As noted above, it happens that there are currently about one billion surface rail passenger-journeys per year in Great Britain, so that the changes in casualties in Table 8 may also be interpreted approximately as changes in casualties per year. Figures 3 and 4 show the changes in fatalities graphically for safety measures (1) and (2) respectively.

Safety measure (1) may be regarded as representative of many general safety measures or collections of safety measures on the railways. It should be noted that any set of safety measures capable of saving $10 \%$ of all casualties would be relatively large and pervasive, but smaller sets of safety measures with the same benefit/cost ratio would give similar conclusions to those below. For example, a safety measure saving $1 \%$ of casualties for a $0.05 \%$ fare rise lead to similar conclusions. The first row of figures in Table 8 and the left-hand block of Figure 3 show that the intended direct effect of measures (1) would be to save 3.3 fatalities or 4.4 fatalities plus weighted injuries per billion passengerjourneys, which are about $10 \%$ of the current numbers per year. These savings are partly to passengers and partly to non-passengers including rail staff and third parties such as users of level crossings. The next three rows in Table 8 and blocks in Figure 3 show the safety effects of the modal shift of journeys from rail to car as a consequence of the rail fare increase. The modal shift leads to fewer rail journeys, fewer access-to-rail journeys, and more car journeys. Table 8 and Figure 3 show that for these kinds of safety measures the secondary effects are small relative to the intended direct rail safety improvement. This is because the assumed fare rise of $0.5 \%$ is small, and therefore the modal shift is small. The intended effects therefore dominate, and the overall savings in casualties are only slightly less than the intended savings. 
Table 9: Changes in casualties per billion rail journeys due to rail safety measures financed by passengers: Great Britain: 2003

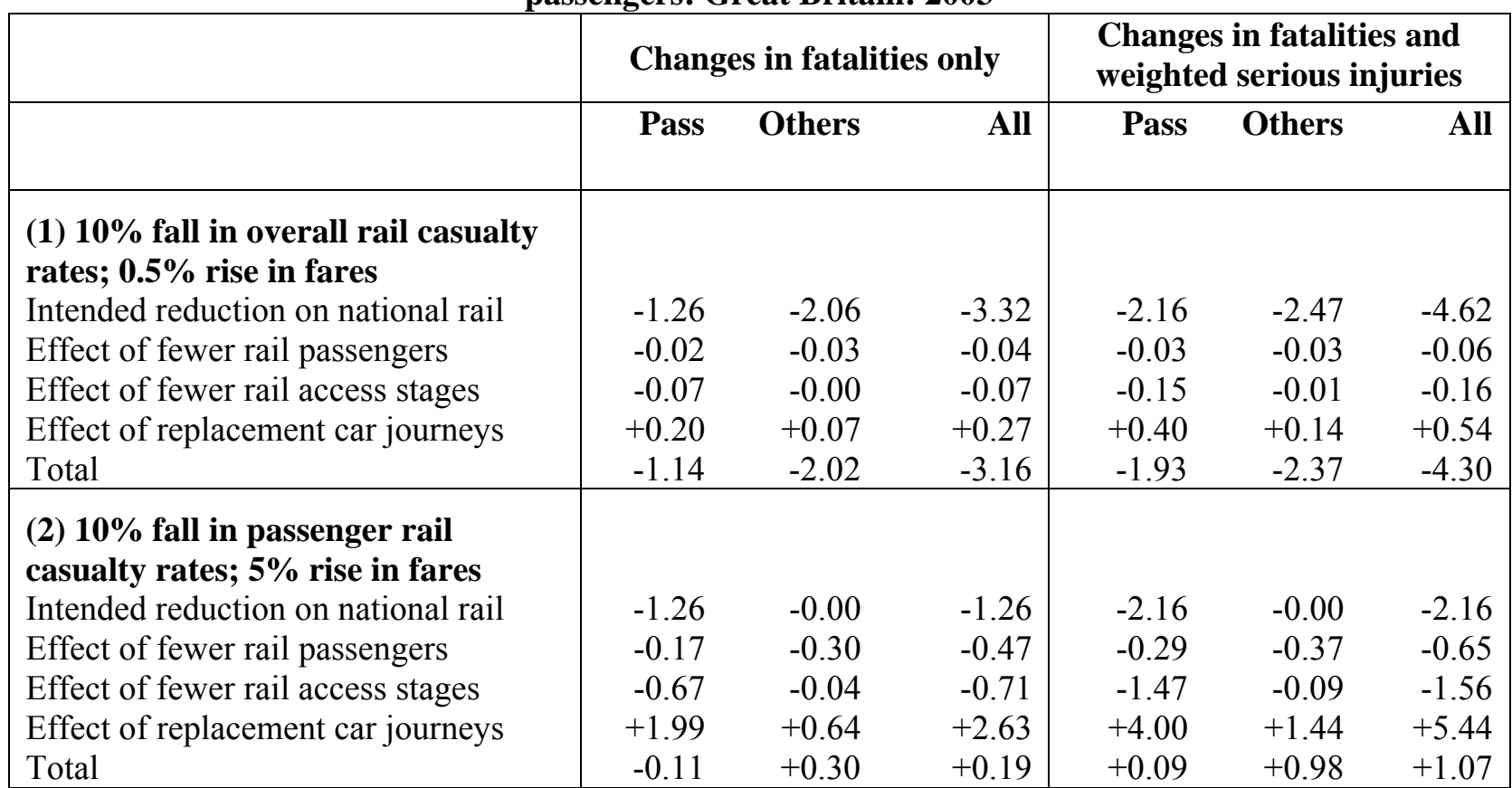

[Figure 3 about here]

The assumed increase in rail fares for safety measures (1) raises about $£ 13$ million per year at 2003/04 prices after allowing for the losses in passengers due to modal transfer. If the $£ 13$ million is divided by the 4.4 rail fatalities and equivalent serious injuries saved per year, the resulting cost per equivalent fatality prevented is $£ 2.9$ million. In reality the cost per equivalent fatality prevented would be less than this, because the safety measures would provide additional benefits besides the prevention of fatalities and serious injuries. These additional benefits would include the prevention of slight casualties, and the avoidance of damage, disruption, and accident investigation costs. After taking these into account, the cost per equivalent fatality prevented might perhaps be of the same order as the 2003 official valuation of preventing fatalities of $£ 1.3$ million (DfT, 2004, Table 1). On most interpretations of the law, such safety measures are required to be implemented on the railways. This contrast with roads, where there is no corresponding requirement. Similar conclusions would apply to smaller or less pervasive safety measures with similar benefit/cost ratios.

Safety measure (2) is representative of a high-cost system safety measure saving casualties to train occupants, such as additional train protection. The $5 \%$ increase in fares would raise $£ 130$ million per year after allowing for the losses in passengers due to modal transfer. This would support a capital sum of about $£ 2$ billion, which is of the order of magnitude of the cost of new train protection systems that have been considered. The reason for supposing that this kind of safety measure would reduce passenger casualties by not more than $10 \%$ is that although the safety measure might be very effective at reducing the type of train accident for which it was designed, it would not reduce personal passenger accidents, such as falls, nor would it reduce other kinds of train accidents, such as those due to rolling stock or infrastructure faults. As noted in section 6, train accidents account for only a minority of passenger casualties. On the other hand, improved train protection would reduce the risk of casualties to on-board train staff as well as to passengers, but their numbers are small relative to passengers, so it is reasonable to disregard them in this representative calculation.

[Figure 4 about here] 
Figure 3: Effect of illustrative rail safety measure saving $10 \%$ of fatalities for $0.5 \%$ increase in fares

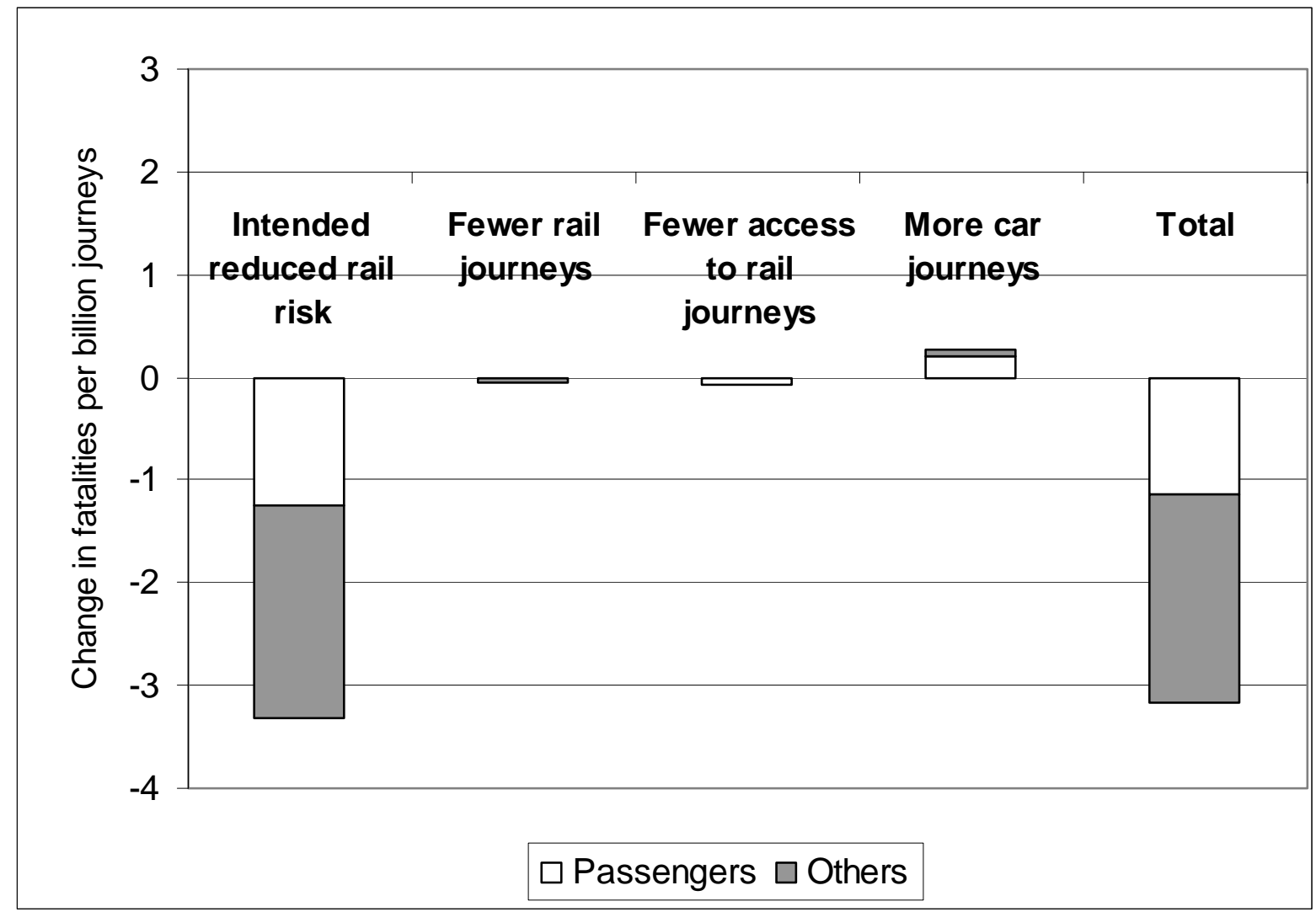

Figure 4: Effect of rail safety measure saving $10 \%$ of only passenger fatalities for $\mathbf{5 \%}$ increase in fares

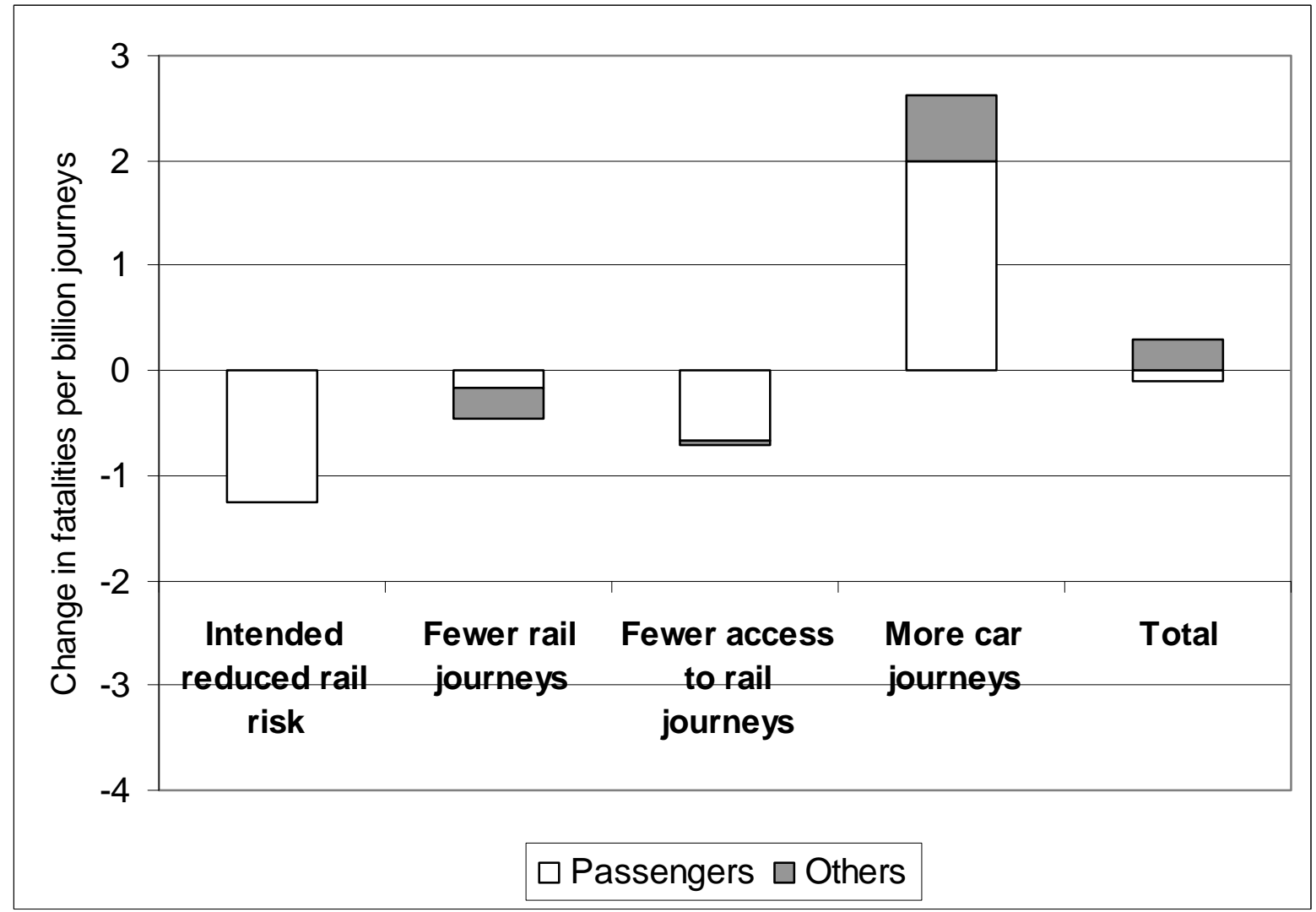


The top row in the bottom half of Table 8 and the first block in Figure 4 show that the intended direct effect safety measure (2) is estimated to reduce rail passenger fatalities by about 1.3 fatalities or 2.2 fatalities and weighted injuries per billion passenger-journeys. However, the secondary safety effects due to modal shift from rail to car are much larger than with safety measures (1) because the assumed fare increase is ten times greater. Two of the secondary effects - fewer rail journeys and fewer accessto-rail journeys - reduce casualties, but these are more than counterbalanced by the additional casualties in the replacement car journeys. The net balance is almost no change in fatalities. The corresponding calculation for the weighted combination of fatalities and serious injuries shows a net increase of about 1 equivalent fatality per billion passenger-journeys.

These results therefore confirm the intuitive expectation that a high-cost railway safety measure that is funded by passengers and has relatively small rail safety benefits could induce a modal shift from rail to car that would negate the intended safety benefit. However, it is perhaps surprising that the effect of modal shift is not larger. One of the explanations is the argument developed in section 4: reducing rail travel reduces access risk as well as on-rail risk, so that the effect of switching from rail to car increases the 'whole journey' risk not by a factor of about 10 , but only by a factor of $2+$. Secondly, Table 7 shows that about $39 \%$ of rail passengers are 'captive' to rail, in the sense that they either come from households without cars or do not hold a driving licence. Such people are assumed not to be able to respond to rail fare increases by switching to the car, and therefore do not contribute to increasing risk by modal shift.

This does not imply that high-cost rail safety measures such as (2) are worthwhile. Even if all the modal shift arguments are disregarded, one is still left with a safety measure costing about $£ 130$ million per year, and saving perhaps 2 on-rail equivalent fatalities per year in fatalities and serious injuries. There would also be other safety benefits besides the prevention of fatalities and serious injuries, as for any safety measure. Even when these are taken into account, the cost per fatality prevented by safety measure (2) would be some tens of millions of £s, compared with the official valuation of preventing a fatality in 2003 of $£ 1.3$ million. That is the primary argument against such safety measures. The argument is reinforced by the arguments about modal shift, but only modestly.

Table 10: Relative fatality risks for pedestrians and car users by age: Great Britain 1998-2000

\begin{tabular}{|c|c|c|c|c|c|}
\hline $\begin{array}{l}\text { Age of } \\
\text { traveller } \\
\text { (years) }\end{array}$ & $\begin{array}{r}\text { Proportion of } \\
\text { rail-km in } \\
\text { given age } \\
\text { group }\end{array}$ & $\begin{array}{r}\text { Proportion of } \\
\text { pedestrian- } \\
\mathrm{km} \text { in given } \\
\text { age group } \\
\end{array}$ & $\begin{array}{r}\text { Proportion of } \\
\text { car user-km } \\
\text { in given age } \\
\text { group }\end{array}$ & $\begin{array}{r}\text { Fatality risk per } \\
\mathrm{km} \text { as pedestrian } \\
\text { of given age } \\
\text { relative to all ages }\end{array}$ & $\begin{array}{r}\text { Fatality risk per } \\
\mathrm{km} \text { as car user of } \\
\text { given age relative } \\
\text { to all ages } \\
\end{array}$ \\
\hline$<17$ & $6.1 \%$ & $24.9 \%$ & $11.5 \%$ & 0.53 & 0.48 \\
\hline $17-20$ & $6.1 \%$ & $6.4 \%$ & $4.7 \%$ & 0.86 & 3.55 \\
\hline $21-29$ & $24.2 \%$ & $12.4 \%$ & $14.3 \%$ & 0.81 & 1.51 \\
\hline $30-39$ & $24.7 \%$ & $15.0 \%$ & $21.5 \%$ & 0.67 & 0.69 \\
\hline $40-49$ & $17.5 \%$ & $11.7 \%$ & $19.3 \%$ & 0.74 & 0.51 \\
\hline $50-59$ & $12.7 \%$ & $11.2 \%$ & $15.8 \%$ & 0.75 & 0.58 \\
\hline $60-69$ & $5.5 \%$ & $9.5 \%$ & $8.1 \%$ & 1.03 & 0.93 \\
\hline$\geq 70$ & $3.3 \%$ & $8.9 \%$ & $4.9 \%$ & 3.89 & 3.05 \\
\hline All ages & $100.0 \%$ & $100.0 \%$ & $100.0 \%$ & 1.00 & 1.00 \\
\hline \multicolumn{4}{|c|}{$\begin{array}{r}\text { Relative risk for pedestrians or car users with same age } \\
\text { distribution as rail users: }\end{array}$} & 0.85 & 1.10 \\
\hline
\end{tabular}


Table 11: Relative fatality risks for pedestrians and car users by time of day: Great Britain 1998-2000

\begin{tabular}{|c|c|c|c|c|c|}
\hline $\begin{array}{l}\text { Time of day of } \\
\text { travel }\end{array}$ & $\begin{array}{r}\text { Assumed } \\
\text { proportion of } \\
\text { rail travel in } \\
\text { given time } \\
\text { period }\end{array}$ & $\begin{array}{r}\text { Proportion } \\
\text { of pedestrian } \\
\text { travel in } \\
\text { given time } \\
\text { period } \\
\end{array}$ & $\begin{array}{r}\text { Proportion } \\
\text { of car travel } \\
\text { in given } \\
\text { time period }\end{array}$ & $\begin{array}{r}\text { Risk of fatality } \\
\text { as pedestrian } \\
\text { in given time } \\
\text { relative to all } \\
\text { times }\end{array}$ & $\begin{array}{r}\text { Risk of } \\
\text { fatality as car } \\
\text { user in given } \\
\text { time relative } \\
\text { to all times }\end{array}$ \\
\hline 06.00 to midnight & $100.00 \%$ & $99.42 \%$ & $98.52 \%$ & 0.88 & 0.85 \\
\hline Midnight to 06.00 & $0.00 \%$ & $0.58 \%$ & $1.48 \%$ & 21.25 & 10.70 \\
\hline All times & $100.00 \%$ & $100.00 \%$ & $100.00 \%$ & 1.00 & 1.00 \\
\hline
\end{tabular}

Table 12: Fatalities per billion traveller-journeys and effect of switching between surface rail and car as main mode for different pedestrian and car user risks

\begin{tabular}{|l|rrrr|}
\hline & \multicolumn{5}{|c|}{ Traveller fatalities per billion journeys } \\
\hline Pedestrian risk & $\begin{array}{r}\text { Base risk } \\
\text { (As Table 4) }\end{array}$ & $\begin{array}{r}\mathbf{7 5 \%} \text { of } \\
\text { base risk }\end{array}$ & Base risk & $\begin{array}{r}\mathbf{7 5 \%} \text { of } \\
\text { base risk }\end{array}$ \\
\hline Car user risk & $\begin{array}{r}\text { Base risk } \\
\text { (As Table 4) }\end{array}$ & Base risk & $\begin{array}{r}\mathbf{7 5 \%} \text { of } \\
\text { base risk }\end{array}$ & $\begin{array}{r}\mathbf{7 5 \%} \text { of } \\
\text { base risk }\end{array}$ \\
\hline Rail & & & & \\
Main rail stage & 12.47 & 12.47 & 12.47 & 12.47 \\
Access stages & 45.95 & 36.52 & 44.46 & 35.02 \\
All journey stages & 58.42 & 48.99 & 56.92 & 47.49 \\
Car: & 135.82 & 135.82 & 101.87 & 101.87 \\
Single stage & & & & \\
Change in fatalities & +77.40 & +86.83 & +44.94 & +54.38 \\
\hline Ratio: car/rail & 2.32 & 2.77 & 1.79 & 2.15 \\
\hline
\end{tabular}

Table 13: Changes in fatalities per billion rail journeys for rail safety measure giving $\mathbf{1 0 \%}$ reduction in passenger fatality rate for $5 \%$ increase in fares

\begin{tabular}{|l|rrrr|}
\hline & \multicolumn{4}{|c|}{ Change in all fatalities per billion journeys } \\
\hline Pedestrian risk & $\begin{array}{r}\text { Base risk } \\
\text { (As Table 4) }\end{array}$ & $\begin{array}{r}75 \% \text { of } \\
\text { base risk }\end{array}$ & Base risk & $\begin{array}{r}75 \% \text { of } \\
\text { base risk }\end{array}$ \\
\hline & $\begin{array}{r}\text { Base risk } \\
\text { (As Table 4) }\end{array}$ & Base risk & $\begin{array}{r}\mathbf{7 5 \%} \text { of } \\
\text { base risk }\end{array}$ & $\begin{array}{r}\mathbf{7 5 \%} \text { of } \\
\text { base risk }\end{array}$ \\
\hline Intended reduction on national rail & & & & \\
Effect of fewer rail passengers & -1.26 & -1.26 & -1.26 & -1.26 \\
Effect of fewer rail access stages & -0.47 & -0.47 & -0.47 & -0.47 \\
Effect of replacement car journeys & -0.71 & -0.58 & -0.69 & -0.55 \\
\hline Total & +2.63 & +2.63 & +1.97 & +1.97 \\
\hline
\end{tabular}

\section{ACKNOWLEDGMENTS}


The work described in this paper was funded by the Engineering and Physical Sciences Research Council in the Future Integrated Transport Programme (GR/R98488/01). The authors are grateful to the Department for Transport for providing some unpublished details of modal casualty data.

\section{REFERENCES}

Department for Transport. National Travel Survey: 1999/2001 update. SB(02)22. Department for Transport, London, 2002

Department for Transport. 2003 valuation of the benefits of prevention of road accidents and casualties. Highways economics note No 1. DfT, London, 2004.

Department for Transport. Road Casualties Great Britain 2003. TSO, London, 2004.

Department for Transport. Transport Statistics Great Britain 2004. TSO, London, 2004.

Department for Transport. Passenger fatality rates by mode of travel. 2003 figures. Transport Trends 2005.

Department for Transport. Focus on personal travel 2005 Edition. TSO, London, 2005.

Health and Safety Executive. HSE's Annual Report on Railway Safety 2003/04. HSE, London, 2004.

Rail Safety and Standards Board. Annual Safety Performance Report 2004. RSSB, London, 2005.

Rail Safety and Standards Board. Profile of safety risk on the UK mainline railway. Issue 4. RSSB, 2005.

Strategic Rail Authority. National Rail Trends 2004-2005. SRA, London, 2005 